DNA barcode variability and host plant usage of fruit flies (Diptera: Tephritidae) in Thailand

\begin{tabular}{|r|l|}
\hline Journal: & Genome \\
\hline Manuscript ID & gen-2015-0110.R2 \\
\hline Manuscript Type: & Article \\
\hline Date Submitted by the Author: & 25-Feb-2016 \\
\hline Complete List of Authors: & $\begin{array}{l}\text { Kunprom, Chonticha; Mahasarakham University, Department of Biology, } \\
\text { Faculty of Science } \\
\text { Pramual, Pairot; Mahasarakham University, Department of Biology }\end{array}$ \\
\hline Keyword: & Bactrocera, DNA barcode, fruit fly, Tephritidae \\
\hline \multicolumn{2}{|l}{} \\
\hline
\end{tabular}

SCHOLARONE ${ }^{\text {IM }}$

Manuscripts 


\section{DNA barcode variability and host plant usage of fruit flies}

\section{(Diptera: Tephritidae) in Thailand}

Chonticha Kunprom ${ }^{1}$, Pairot Pramual ${ }^{1,2^{*}}$

${ }^{1}$ Department of Biology, Faculty of Science, Mahasarakham University, Kantharawichai District, Maha Sarakham 44150 Thailand

${ }^{2}$ Biodiversity and Traditional Knowledge Research Unit, Faculty of Science, Mahasarakham University, Kantharawichai District, Maha Sarakham 44150 Thailand

*Corresponding Author:

Pairot Pramual

Department of Biology, Faculty of Science, Mahasarakham University,

Maha Sarakham 44150 Thailand

Email: pairot.p@msu.ac.th

Phone: 66-43754245

Fax: 66-43754245

Running title: DNA barcoding of fruit flies in Thailand 


\begin{abstract}
The objectives of this study were to examine the genetic variation in fruit flies (Diptera: Tephritidae) in Thailand and to test the efficiency of the mitochondrial cytochrome $c$ oxidase subunit I (COI) barcoding region for species-level identification. Twelve fruit fly species were collected from 24 host plant species of 13 families. The number of host plant species for each fruit fly species ranged between one and 11, with Bactrocera correcta found in the most diverse host plants. A total of $123 \mathrm{COI}$ sequences were obtained from these fruit fly species. Sequences from the NCBI database were also included, for a total of 17 species analyzed. DNA barcoding identification analysis based on the best-close match method revealed a good performance, with $94.4 \%$ of specimens correctly identified. However, many specimens (3.6\%) had ambiguous identification, mostly due to intraspecific and interspecific overlap between members of the $B$. dorsalis complex. A phylogenetic tree based on the mitochondrial barcode sequences indicated that all species, except for the members of the $B$. dorsalis complex, were monophyletic with strong support. Our work supports recent calls for synonymization of these species. Divergent lineages were observed within B. correcta and $B$. tuberculata, and this suggested that these species need further taxonomic reexamination.
\end{abstract}

Key words: Bactrocera, DNA barcode, fruit fly, host specificity, Tephritidae 


\section{Introduction}

Fruit flies (Diptera: Tephritidae) are among the most important insect pests of fruits and vegetables. Globally, there are approximately 5000 described species of fruit flies assigned into six subfamilies (Uchôa 2012). Most pest species of Tephritidae belong to the genera Anastrepha Schiner, Bactrocera Macquart, Ceratitis Macleay, Dacus Fabricius, and Rhagoletis Loew (White and Elson-Harris 1992; Van Houdt et al. 2010). The genus

Bactrocera is one of the largest genera of Tephritidae, with more than 600 described species arranged in 30 subgenera (Drew 1989, 2004; Drew and Hancock 1994). Several species of the genus Bactrocera are capable of infesting a wide variety of economically important fruits and vegetables (White and Elson-Harris 1992; Allwood et al. 1999; Clarke et al. 2005). For example, the Bactrocera dorsalis (Hendel) species complex, which includes more than 75 sibling species, can infest nearly 200 host plant species from 50 plant families (Drew 1989; Drew and Hancock 1994; Hollingsworth et al. 2003; Clarke et al. 2005; Kumar et al. 2011). Rapid and accurate identification of specimens at the species level is a primary requirement for all aspects of fruit fly biology and management (Armstrong and Ball 2005; Jinbo et al. 2011). However, morphological identification of fruit flies has some limitations. The taxonomic identification of fruit flies based on morphology for the immature stages (i.e. egg, larva, and pupa) is extremely difficult because of a lack of diagnostic characters to distinguish species (Armstrong et al. 1997). Morphological identification is reliable only in the adult stage, but faces difficulties in the case of high within-species variation or morphological similarity of closely-related species, such as found within species complexes. The classic example is the case of the $B$. dorsalis species complex. Three species, namely $B$. papayae Drew and Hancock, B. philippinensis Drew and Handcock, and B. invadens Drew, Tsuruta and White, were recognized as different species based on morphological differences (e.g. abdominal color patterns, aedeagus length, wing shape, postsutural lateral vittae and 
thoracic color patterns). However, multidisciplinary studies including molecular genetics (using the nuclear ribosomal internal transcribed spacer (ITS), mitochondrial cytochrome $c$ oxidase subunit I (COI) and NADH dehydrogenase 4 (ND4) genes), cytogenetics, mating compatibility, and chemoecology suggested that these species should be merged into a single biological species with $B$. dorsalis (Schutze et al. 2015a). The cytogenetic technique has also contributed to fruit fly taxonomy (Zacharopoulou et al. 2011), which can be used to differentiate the members of some species complexes (Baimai et al. 2000). However, cytological taxonomy requires high levels of personal expertise for interpretation and is workable only for some species because of poor quality in visualization of the chromosomes. Previous studies have shown that DNA barcodes could effectively be used to identify fruit fly species (Armstrong and Ball 2005). The barcode region (Hebert et al. 2003; Ratnasingham and Hebert 2007) of the COI sequences have been used successfully for specimen identification to the species level (Armstrong and Ball 2005; Blacket et al. 2012), although discriminating members of species complexes was less successful (Barr et al. 2012; Blacket et al. 2012; Jiang et al. 2014). In this study, we investigated the efficiency of DNA barcoding for identification of morphospecies of fruit flies of the genus Bactrocera in Thailand. Although several studies have now used COI barcode sequences in Bactrocera, the success of this method still relies mainly on the availability of the database (Virgilio et al. 2010; Jinbo et al. 2011). In addition, it is also preferable for genetic variation across the geographic range of the species to be included in the database. Thus, specimens from a wide geographical range should be included to acknowledge intraspecific genetic variation (Meyer and Paulay 2005). In Thailand, fruit flies are highly diverse: there are at least 103 species from 15 subgenera of four genera (Bactrocera, Dacus, Ichneumonopsis, Monacrostichus) recorded in the country (Drew and Romig 2013). DNA barcode sequences have only been reported from seven species (Bactrocera correcta (Bezzi), B. latifrons (Hendel), B. umbrosa 
(Fabricius), B. zonata (Saunders), B. caudata (Fabricius), B. isolata (Hardy), B. rubella

(Hardy)) (Meeyen et al. 2014; Jiang et al. 2014; Kunprom et al. 2015). Therefore, our results would increase the sequence library for fruit fly species in Thailand, and this will encourage rapid and accurate specimen identification. We also report the host plant species of the fruit flies included in our study, which is generally lacking in previous DNA barcode studies of the Tephritidae. This information will be useful for further control and management as well as fruit fly biology studies.

\section{Materials and Methods}

\section{Sample collection and morphological identification}

Fruit fly specimens were collected from 25 sites in Thailand between March 2012 and February 2015 (Table 1 and Fig.1). The infested fruits from 24 host plant species belonging to 13 families were obtained from both natural forests and fruit orchards (Table 2). The infested fruit was placed in plastic boxes containing sawdust in the bottom, covered by calico, and kept at room temperature until adults emerged. Adult flies were collected and stored in $80 \%$ ethanol at $-20^{\circ} \mathrm{C}$. Voucher specimens were kept at Department of Biology, Faculty of

Science, Mahasarakham University, Thailand. Species were identified morphologically using the keys and descriptions of White and Elson-Harris (1992), Plant Health Australia (2011), and Drew and Romig (2013).

\section{DNA extraction, amplification and sequencing}

Genomic DNA was extracted from each adult fly, randomly chosen from each host plant species from each collecting locality using the GF-1 Tissue DNA Extraction Kit (Vivantis, Selangor Darul Ehsan, Malaysia) following the manufacture's protocol, with a final elution volume of $100 \mu$ l. A portion of the mitochondrial cytochrome $c$ oxidase I (COI) 
gene was amplified using the primers LCO1490 (5'-

GGTCAACAAATCATAAAGATATTGG-3') and HCO2198 (5'-TAAACTTCAG

GGTGACCAAAAAATCA-3') (Folmer et al. 1994). Polymerase chain reactions (PCR) were carried out in a final volume of $50 \mu 1$ containing $2 \mu 1$ of DNA template, $2 \mu 1$ of each primer $(10 \mu \mathrm{M}), 3 \mu \mathrm{l}$ of $50 \mathrm{mM} \mathrm{MgCl} 2,5 \mu \mathrm{l}$ of $10 \mathrm{x}$ PCR buffer, $1.6 \mu \mathrm{l}$ of $10 \mu \mathrm{M}$ dNTPs, and $0.4 \mu \mathrm{l}$ of Taq DNA polymerase $(5 \mathrm{U} / \mu \mathrm{l})$. The temperature profile of the PCR included an initial denaturation at $94^{\circ} \mathrm{C}$ for 2 min followed by 36 cycles of $94^{\circ} \mathrm{C}$ for $30 \mathrm{sec}, 45^{\circ} \mathrm{C}$ for $45 \mathrm{sec}$, and $72^{\circ} \mathrm{C}$ for $45 \mathrm{sec}$ with the final extension at $72^{\circ} \mathrm{C}$ for $5 \mathrm{~min}$. PCR products were checked with a $1 \%$ agarose gel and purified using the HiYield Gel/PCR DNA Extraction Kit (RBC Bioscience). Sequencing was performed in both directions at Macrogen (Seoul, Korea) using the same primers as in the PCR. DNA sequences were aligned using CLUSTAL X (Thompson et al. 1997), with a final visual inspection. Sequences were translated into amino acids to verify that they were correct using MEGA 6 (Tamura et al. 2013).

\section{Data analysis}

A total of $1146 \mathrm{COI}$ sequences were included in the analyses. One hundred and twenty three sequences (GenBank accession numbers: KT588319-KT588441) were obtained in this study, and the remainder were from GenBank. Sequences from GenBank were obtained using the species name as the key word to search for the data. We included all of the available sequences in GenBank of the species that we detected during our study plus sequences of the species that know to occur in Thailand. In total, 17 species were included in the data analysis; 12 were obtained in the present study, and five were from GenBank. According to a previous suggestion (Schutze et al. 2015a), members of the $B$. dorsalis complex (B. dorsalis, B. invadens, B. papayae, B. philippinensis) were treated as a single morphological species for phylogenetic analysis. However, the original morphological 
identifications were retained for the detailed presentation of the tree of this species complex. Intraspecific and interspecific genetic divergences were calculated based on the Kimura 2parameter (K2P) model using MEGA 6 (Tamura et al. 2013). The frequency of successful identification was tested using the best match and best close match methods in the program TaxonDNA (Meier et al. 2006). The best match method assigns specimens to species according to the best-matching barcode sequence (Meier et al. 2006). The best close match method assigns specimens to species based on the level of sequence similarity below the threshold value, which is $95 \%$ of all intraspecific distances (Meier et al. 2006). The published sequences of all species were used as the reference data set for the best close match analysis. All unique haplotypes $(n=461)$ were used to infer phylogenetic relationships using the maximum-likelihood (ML) method implemented in PhyML 3.0 (Guindon et al. 2010). Node support was calculated using approximate likelihood ratio tests (Anisimova and Gascuel 2006). The program jModeltest v.2.1.9 (Darriba et al. 2012) was used to select the best-fit DNA substitution model for the ML analysis based on the Akaike information criterion (AIC). The best-fit model was the general time-reversible (GTR) model with a proportion of invariable sites of 0.382 and with a gamma distribution of 1.006. Ceratitis capitata (Wiedemann) and Rhagoletis pomonella (Walsh) (GenBank accession numbers DQ116370 and DQ116382, respectively) were used as the outgroups (Krosch et al. 2012). To present the relationship between the host plant and the fruit fly phylogeny, information about the host plant families from Table 2 were mapped onto the ML tree.

\section{Results}

\section{Fruit fly species and host plant diversity}

A total of 12 fruit fly species was collected in this study (Table 2). Among these, there were 11 known, and one was an unknown species (Bactrocera sp. 1) of the subgenus 
Javadacus. These species were collected from 24 host plant species of 13 families (Table 2). B. correcta is the fruit fly species that was found from the most diverse range of host plants in this study. This species was collected from 11 plant species distributed in 10 plant families. Bactrocera (Zeugodacus) scutellaris (Bezzi), B. (Bactrocera) thailandica Drew and Hancock, B. (Bactrocera) tuberculata (Bezzi), B. (Gymnodacus) symplocos Drew and Romig, B. (Hemigymnodacus) diversa (Coquillett), and Bactrocera sp. 1 were collected from only a single host plant species each (Table 2).

\section{COI barcode sequence variation and DNA barcode statistics}

A total of 1146 sequences from 17 fruit fly species (12 species collected in the present study and 5 species obtained from GenBank) of the genus Bactrocera were included in the data analysis. Intraspecific genetic divergence based on $\mathrm{K} 2 \mathrm{P}$ genetic distances ranged from $0 \%$ to $10.47 \%$, with a mean of $0.64 \%$ (Table 3 ). The maximum intraspecific genetic divergence was found in $B$. dorsalis complex (10.47\%). The K2P genetic distance to the closest species ranged from $0 \%$ to $15.88 \%$. Low interspecific genetic divergences $(0 \%)$ were found among members of the B. dorsalis complex (i.e. B. carambolae and B. dorsalis). Specimens of B. tau and B. cucurbitae also showed very low genetic divergence, with a minimum K2P value of $0.88 \%$. Levels of intraspecific and interspecific genetic divergence values showed overlap for four species (Fig. 2). To compare our results based only on species that occur in Thailand with all available sequences of genus Bactrocera in the public database, we performed a barcode gap analysis in BOLD (Ratnasingham and Hebert 2007; accessed 18 February 2016). In total, 1669 sequences represent 68 species were included in the analysis. The levels of intraspecific ( $0 \%$ to $12.49 \%$, mean $1.63 \%)$ and interspecific genetic divergence (smallest pairwise distance to the nearest neighbor species, $0 \%$ to $12.63 \%$, mean 3.5\%) were similar to our data. However, some COI sequences in this database could 
be from misidentified specimens. For example, the same COI haplotype was found for morphologically highly different species, such as B. carambolae and B. cucurbitae. This could be a limitation of using all sequences from public databases for conduct barcode-based identifications.

The best match and best close match methods revealed similar levels of correct specimen identification to species (Table 4). The overall percent correct specimen identification for the best close match method was $94.42 \%$ (1 105 of 1146 sequences), $2.87 \%$ was for ambiguous identification (33 sequences), and $0.52 \%$ was for misidentification (six sequences). Two sequences $(0.17 \%)$ were without any match closer than the threshold value $(2.05 \%)$, which is a genetic distance at $95 \%$ of all intraspecific genetic distances. With only two exceptions for B. cucurbitae and one for B. tau that show low $(<0.88 \%)$ interspecific genetic divergence, all sequences that were ambiguous or displayed misidentifications were from members of the $B$. dorsalis complex. One haplotype was shared by different species $(B$. dorsalis and B. carambolae) of the members of the B. dorsalis complex.

\section{Phylogenetic relationships}

A maximum likelihood (ML) tree (Fig. 3) revealed two main clades (clades I and II). Clade I was comprised of eight species of the subgenus Bactrocera, including three species of the B. dorsalis complex (B. carambolae, B. dorsalis, B. thailandica), B. correcta, B. latifrons, B. umbrosa, B. zonata, and B. tuberculata, and one species of the subgenus Gymnodacus (B.(Gymnodacus) symplocos). Clade II was comprised of six species of the subgenus Zeugodacus (B. caudata, B. cucurbitae, B. isolata, B. rubella, B. scutellaris, B. tau complex), one species of the subgenus Hemigymnodacus (B. diversa), and one unknown species (Bactrocera sp. 1). Clade II was further divided into two subclades. B. caudata, $B$. isolata, B. rubella, B. scutellaris and B. diversa comprised clade II-1. B. cucurbitae, B. tau 
complex, and one unknown species (Bactrocera sp. 1) formed clade II-2. At the species level, all species were monophyletic with strong bootstrap support, except for members of the $B$. dorsalis complex (Fig. 4). Three species (B. invadens, B. papayae, B. philippinense) were recently treated as the synonyms of $B$. dorsalis (Schutze et al. 2015a) and formed a single clade (Fig. 4). Thus, our results supported this synonymization. Another member of the $B$. dorsalis complex, B. carambolae, was treated as a valid species based on multidisciplinary evidence (Schutze et al. 2015). The ML tree partially supported this as most of the haplotypes of this species formed a single clade, although two haplotypes of $B$. dorsalis were also included in this clade (Fig. 4). Specimens of an unknown species, Bactrocera sp. 1, formed a monophyletic clade with strong support (posterior probability $=1$ ).

Members of the fruit fly species in clade I were found in diverse host plant families, notably, B. dorsalis and B. correcta (Fig. 3). All 13 families (20 species) of the host plants recorded in this study were exploited by the fruit fly species in clade I. In contrast, only two plant families (five species) were recorded for the fruit fly species in clade II. The family Cucurbitaceae is the major host plant for the fruit fly species in this clade (Fig. 3).

\section{Discussion}

The primary objective of the DNA barcode method is to identify unknown specimens to known species using a short DNA sequence (Hebert et al. 2003). Previous studies indicated that the DNA barcoding technique based on COI sequences was effective for specimen identification of fruit flies (Armstrong and Ball 2005; Barr et al. 2012; Blacket et al. 2012) as well as other insects (e.g., Pramual and Adler 2014). Our results revealed a good performance (96.42\% correct identification) of the DNA barcode for identification of morphospecies of fruit flies in Thailand. However, a considerable proportion (3.58\%, 41 sequences) of unsuccessful identification (ambiguous and incorrect identification) was also revealed. Nearly 
all of the ambiguous or incorrect identifications were due to overlapping intraspecific and interspecific genetic divergences among members of the $B$. dorsalis complex (i.e., between $B$. dorsalis and B. carambolae). A previous study also found that the existence of a species complex reduced the efficiency of the DNA barcode for species differentiation. Jiang et al. (2014) found that when species complexes (B. dorsalis and B. tryoni complexes) were included in the analysis, the DNA barcode only had successful identification for $74 \%$ of species.

Unsuccessful identification of the $B$. dorsalis complex was correlated to the phylogenetic analysis based on COI barcoding sequences that found the members of the $B$. dorsalis complex included in this study (B. carambolae, B. dorsalis) were not recovered as reciprocally monophyletic. Several factors could explain this phenomenon including (i) incomplete lineage sorting, (ii) interspecific introgression, (iii) inadequate phylogenetic signal for the DNA sequences being used, and (iv) imperfect taxonomy (Funk and Omland 2003).

High intraspecific genetic divergences were found among the members of $B$. dorsalis, and the successful identification of other species suggested that the COI sequence used in this study possessed enough variation. Extensive taxonomic studies of the $B$. dorsalis species complex based on a multidisciplinary approach using morphology, molecular genetics, cytogenetics, sexual compatibility, and chemoecology (Schutze et al. 2012, 2015a, b; Boykin et al. 2014) provided consistent evidence to support B. papayae, B. philippinensis, and $B$. invadens as junior synonyms of $B$. dorsalis, while $B$. carambolae was retained as a valid species (Schutze et al. 2015a). According to these studies, imperfect taxonomy is unlikely to explain the species non-monophyly of $B$. dorsalis and $B$. carambolae. Therefore, the most likely explanations are incomplete lineage sorting and interspecific introgression. Although B. carambolae was treated as the valid biological species, this species is closely related to $B$. 
dorsalis (Schutze et al. 2015a). Phylogenetic analysis based on multiple gene sequences also found that B. carambolae is nested within the paraphyletic B. dorsalis clade (San Jose et al. 2013). As these species are closely related, incomplete lineage sorting could explain the species non-monophyly, which led to unsuccessful barcode-based identifications. Interspecific introgression could also explain this situation. Although the two species are valid biological species, and differentiation in mating behavior resulting in a low rate of interbreeding was observed (Schutze et al. 2013), a field cage study revealed that interspecific hybridization could occur between these species (McInnis et al. 1999).

In addition to providing a rapid and accurate method for specimen identification, DNA barcoding can also reveal hidden diversity. Our results revealed that five species $(B$. correcta, B. cucurbitae, B. dorsalis, B. carambolae, B. tuberculata) possessed high ( $>3 \%)$ intraspecific genetic divergence. Previous studies in other insects, such as black fly (Simuliidae) (Pramual and Adler 2014), freshwater midge (Chironomidae) (Proulx et al. 2013), and fruit fly (Jiang et al. 2014), suggested that species possessing intraspecific genetic variation higher than $3 \%$ were likely to be a species complex. Two genetically divergent lineages were revealed in the phylogenetic analysis of $B$. correcta. The results were consistent with previous studies. Population genetics and molecular phylogenetic studies of B. correcta in Thailand found two genetically divergence lineages of this species (Jamnongluk et al. 2003a; Kunprom et al. 2015). These lineages were geographically sympatric and found on the same range of host plant species. Examination of the relationship between host plant families and genetic lineages on the ML tree of this species revealed no apparent association (Fig. 5). Therefore, it is likely that they are two genetically divergent species, but morphologically similar within the B. correcta morphospecies. Further investigation is required to determine its taxonomic status. 
Specimens of $B$. tuberculata included in this study also showed two divergent lineages. These lineages were associated with geographic origin, i.e., Thailand and China. Genetic differentiation between these lineages was high (3.87\%). Thus, it is likely that they could be distinct species. Morphological comparisons with the photographs of this species in the DNA barcode database (www.boldsystems.org) revealed that they were slightly different on the abdomen. B. tuberculata from Thailand collected in this study had a pale fulvous on the tergum II at the position adjoining the tergum III, with a narrow transverse black band across the anterior edge reaching the narrow black lateral edge. These characters agree well with the description of this species by Drew and Roming (2013). In contrast, the specimen of B. tuberculata from China reported in BOLD had a fulvous tergum II adhering to the tergum III, but the narrow transverse black band did not reach the lateral edges. Therefore, the taxonomic status of these species needs reexamination.

Bactrocera sp.1 was collected from Coccinia grandis (L.) Voigt. This species was morphologically classified into the subgenus Javadacus as it had a pair of scutellar setae and prescutellar setae, anterior supra-alar and postpronotal setae absent. All male specimens had a pecten of cilia on the abdominal tergum III and a posterior lobe of the male surstylus long. These characteristics are considered to be the dominant features of the subgenus Javadacus (Drew and Roming 2013). Bactrocera sp. 1 is similar to B. trilineata. They are also found on the same major host plant, C. grandis of the family Cucurbitaceae. However, Bactrocera sp. 1 could be differentiated from $B$. trilineata by the color of the abdominal tergum III.

Bactrocera sp. 1 had a broad transverse black band across the tergum III covering two-thirds of the tergum, but $B$. trilineata had a broad transverse black band across the tergum III covering almost the entire tergum. The scapular setae on the thorax was the most distinctive character differentiating Bactrocera sp. 1 from B. trilineata. The former species had two scapular setae, while the latter had four. There are no reports for the COI barcoding sequence 
of B. trilineata; thus, we were unable to compare these species. Therefore, further taxonomic work is needed to clarify the species status of Bactrocera sp. 1.

Bactrocera tau in Thailand was proposed to be a species complex comprised of nine (A - I) cryptic species (Baimai et al. 2000; Sumrandee et al. 2011). Molecular genetics and morphometric analysis of the wing shape supported the distinctions of some species within the complex (Jamnongluk et al. 2003b; Thanaphum and Thaenkham 2003; Kitthawee and Dujardin 2010; Dujardin and Kitthawee 2013). Our results, however, revealed a single monophyletic lineage with low genetic diversity for $B$. tau. The most likely explanation for this situation is that our specimens represent a single species, B. tau A. Although we were not able to identify our specimens of $B$. tau into cryptic species because this would have required a close examination of the microscopic morphology of the shape of the ovipositor (Sumrandee et al. 2011), Baimai et al. (2000) suggested that geographic origin and host plant could be used for cryptic species recognition in this species. Our specimens were collected from the north and northeast of Thailand from three host plant species that only $B$. tua A was recorded from. Therefore, it is likely that our specimens included in this study represent only a single species (i.e. B. tau A) of the $B$. tau species complex. The addition of other species within the $B$. tau complex is needed for fully understanding the genetic diversity and efficiency of the DNA barcode for cryptic species delimitation in this group.

In conclusion, our results indicated that COI barcode sequences were successful for identifying fruit fly species in Thailand. However, the efficiency of this barcoding sequence was limited when members of a species complex were included in the analysis. A further limitation was found when sequences from a public database were used where species identification is uncertain, such as morphologically highly different species having the same COI sequence or the same species name being applied for highly divergence COI sequences. A similar problem has been reported in other barcoding studies of insects such as in 
Chironomidae (Pramual et al. 2016). This indicates that care must be taken to examination the identification source and method when using full public databases to obtain species-level identifications. Levels of host plant specificity vary across fruit fly species. Members of the subgenus Bactrocera were found in diverse host plants. while those of the subgenus Zeugodacus were confined to host plants of the family Cucurbitaceae. There was no evidence of association between the intraspecific genetic lineages and the host plant species. However, the limitation of the host plant information for the sequence data from public database prevented us from confirming this, and further examination will be required.

\section{Acknowledgements}

This work was financially supported by a grant from Mahasarakham University. We thank Jolyon Dodgson (Mahasarakham University, Thailand) for valuable comments on an earlier version of the manuscript.

\section{References}

Allwood, A.J., Chinajariyawong, A., Drew, R.A.I., Hamacek, E.L., Hancock, D.L., Hengsawad, J.C., Jirasurat, M., Kong Krong, C., Kritsaneepaiboon, S., Leong. C.T.S., and Vijaysegaran, S. 1999. Host-plant records for fruit flies (Diptera: Tephritidae) in South East Asia. Raffles B. Zool. 1-92(suppl. 7).

Anisimova, M., and Gascuel, O. 2006. Approximate likelihood-ratio test for branches: a fast, accurate, and powerful alternative. Syst. Biol. 55: 539-552.

Armstrong, K.F., and Ball, S.L. 2005. DNA barcodes for biosecurity: invasive species identification. Philos. T. Roy. Soc. B 360: 1813-1823.

Armstrong, K.F., Cameron, C.M., and Frampton, E.R. 1997. Fruit fly (Diptera: Tephritidae) 
species identification: a rapid molecular diagnostic technique for quarantine application. B. Entomol. Res. 87: 111-118.

Baimai, V., Phinchongsakuldit, J., Sumrandee, C., and Tigvattananont, S. 2000. Cytological evidence for a complex of species within the taxon Bactrocera tau (Diptera: Tephritidae) in Thailand. Biol. J. Linn. Soc. 69(3): 399-409.

Barr, N.B., Islam, M.S., de Meyer, M., and McPheron, B.A. 2012. Molecular identification of Ceratitis capitata (Diptera: Tephritidae) using DNA sequences of the COI barcode region. Ann. Entomol. Soc. Am. 105: 339-350.

Blacket, M.J., Semeraro, L., and Malipatil, M.B. 2012. Barcoding Queensland fruit flies (Bactrocera tryoni): impediments and improvements. Mol. Ecol. Resour. 12: 428436.

Boykin, L.M., Schutze, M.K., Krosch, M.N., Chomič, A., Chapman, T.A., Englezou, A., Armstrong, K.F., Clarke, A.R., Hailstones, D., and Cameron, S.L. 2014. Multi-gene phylogenetic analysis of south-east Asian pest members of the Bactrocera dorsalis species complex (Diptera: Tephritidae) does not support current taxonomy. J. Appl. Entomol. 138(4): 235-253.

Clarke, A.R., Armstrong, K.F., Carmichael, A.E. Milne, J.R., Raghu, S., Roderick, G.K., and Yeates, D.K. 2005. Invasive phytophagous pests arising through a recent tropical evolutionary radiation: the Bactrocera dorsalis complex of fruit flies. Annu. Rev. Entomol. 50: 293-319.

Darriba, D., Taboada, G.L, Doallo, R., and Posada, D. 2012. jModelTest 2: more models, new heuristics and parallel computing. Nat. Methods, 9(8): 772.

Drew, R.A.I. 1989. The tropical fruit flies (Diptera: Tephritidae: Dacinae) of the Australasian and Oceanian regions. Mem. Queensl. Mus. 26: 1-521. 
Drew, R.A.I. 2004. Biogeography and speciation in the Dacini (Diptera: Tephritidae: Dacinae). Bishop Mus. Bull. Entomol. 12: 165-178.

Drew, R.A.I., and Hancock, D.L. 1994. The Bactrocera dorsalis complex of fruit flies (Diptera: Tephritidae: Dacinae) in Asia. B. Entomol. Res. 1-68(Suppl. 2).

Drew, R.A.I., and Romig, M.C. 2013. Tropical Fruit Flies (Tephritidae Dacinae) of SouthEast Asia: Indomalaya to North-West Australasia. CABI.

Dujardin, J. P., and Kitthawee, S. 2013. Phenetic structure of two Bactrocera tau cryptic species (Diptera: Tephritidae) infesting Momordica cochinchinensis (Cucurbitaceae) in Thailand and Laos. Zoology, 116(2): 129-138.

Folmer, O., Black, M., Hoeh, W., Lutz, R., and Vrijenhoek, R. 1994. DNA primers for amplification of mitochondrial cytochrome $c$ oxidase subunit I from diverse metazoan invertebrates. Mol. Mar. Biol. Biotech. 3: 294-299.

Funk, D.J., and Omland, K.E. 2003. Species-level paraphyly and polyphyly: frequency, causes, and consequences, with insights from animal mitochondrial DNA. Annu. Rev. Ecol. Syst. 34: 397-423.

Guindon, S., Dufayard, J.F., Lefort, V., Anisimova, M., Hordijk, W., and Gascuel, O. 2010. New algorithms and methods to estimate maximum-likelihood phylogenies: assessing the performance of PhyML 3.0. Syst. Biol. 59: 307-321.

Hebert, P.D.N., Cywinska, A., Ball, S.L., and de Waard, J.R. 2003. Biological identifications through DNA barcodes. P. Roy. Soc. B-Biol. Sc. 270: 313-321.

Hollingsworth, R.G., Drew, R.A., Allwood, A.J., Romig, M., Vagalo, M., and Tsatsia, F. 2003. Host plants and relative abundance of fruit fly (Diptera: Tephritidae) species in the Solomon Islands. Aust. J. Entomol. 42(2): 95-108.

Jamnongluk, W., Baimai, V., and Kittayapong, P. 2003a. Molecular evolution of tephritid 
fruit flies in the genus Bactrocera based on the cytochrome oxidase I gene. Genetica, 119: 19-25.

Jamnongluk, W., Baimai, V., and Kittayapong, P. 2003b. Molecular phylogeny of tephritid fruit flies in the Bactrocera tau complex using the mitochondrial COI sequences. Genome, 46(1): 112-118.

Jiang, F., Jin, Q., Liang, L., Zhang, A.B., and Li, Z.H. 2014. Existence of species complex largely reduced barcoding success for invasive species of Tephritidae: a case study in Bactrocera spp. Mol. Ecol. Resour. 14(6): 1114-1128.

Jinbo, U., Kato, T., and Ito, M. 2011. Current progress in DNA barcoding and future implications for entomology. Entomol. Sci. 14: 107-124.

Kitthawee, S., and Dujardin, J. P. 2010. The geometric approach to explore the Bactrocera tau complex (Diptera: Tephritidae) in Thailand. Zoology, 113(4): 243-249.

Krosch, M. N., Schutze, M. K., Armstrong, K. F., Graham, G. C., Yeates, D. K., and Clarke, A. R. 2012. A molecular phylogeny for the Tribe Dacini (Diptera: Tephritidae): Systematic and biogeographic implications. Mol. Phylogenet. Evol. 64(3): 513-523.

Kumar, P., Alma, L.A., Ketelaar, J., and Shanmugam, V. 2011. Field Exercise Guide on Fruit Flies Integrated Pest Management: Area-wide Ingetrated Pest Management of Fruit Flies in South and Southeast Asia Countries. Bangkok, Asian Fruit Fly IPM Project.

Kunprom, C., Sopaladawan, P.N., and Pramual, P. 2015. Population genetics and demographic history of guava fruit fly Bactrocera correcta (Diptera: Tephritidae) in northeastern Thailand. Eur. J. Entomol. 112(2): 227.

McInnis, D. O., Rendon, P., Jang, E., van Sauers-Muller, A., Sugayama, R., and Malavasi, A. 1999. Interspecific mating of introduced, sterile Bactrocera dorsalis with wild $B$. carambolae (Diptera: Tephritidae) in Suriname: a potential case for cross-species sterile insect technique. Ann. Entomol. Soc. Am. 92(5): 758-765. 
Meeyen, K., Nanorksopaldawan, P., and Pramual, P. 2014. Population structure, population history and DNA barcoding of fruit fly Bactrocera latifrons (Hendel) (Diptera: Tephritidae). Entomol. Sci. 17: 219-230.

Meier, R., Shiyang, K., Vaidya, G., and Ng, P.K.L. 2006. DNA barcoding and taxonomy in Diptera: a tale of high intraspecific variability and low identification success. Systematic Biol. 55: 715-728.

Meyer, C.P., and Paulay, G. 2005. DNA barcoding: error rates based on comprehensive sampling. Public Library of Science Biology, 3: e422.

Plant Health Australia 2011. The Australian Handbook for the Identification of Fruit Flies. Version 1.0. Plant Health Australia, Canberra, ACT.

Pramual, P., and Adler, P.H. 2014. DNA barcoding of tropical black flies (Diptera: Simuliidae) of Thailand. Mol. Ecol. Resour. 14(2): 262-271.

Pramual, P., Simwisat, K., and Martin, J. 2016. Identification and reassessment of the specific status of some tropical freshwater midges (Diptera: Chironomidae) using DNA barcode data. Zootaxa, 4072(1): 39-60.

Proulx, I., Martin, J., Carew, M., and Hare, L. 2013. Using various lines of evidence to identify Chironomus species (Diptera: Chironomidae) in eastern Canadian lakes. Zootaxa, 3741: 401-458.

Ratnasingham, S., and Hebert, P.D.N. 2007. BOLD: The Barcode of Life Data System (www.barcodinglife.org). Mol. Ecol. Notes 7: 355-364.

San Jose, M., Leblanc, L., Geib, S. M., and Rubinoff, D. 2013. An evaluation of the species status of Bactrocera invadens and the systematics of the Bactrocera dorsalis (Diptera: Tephritidae) complex. Ann. Entomol. Soc. Am. 106(6): 684-694.

Schutze, M. K., Aketarawong, N., Amornsak, W., Armstrong, K. F., Augustinos, A. A., Barr, 
N., Bo, W., Bourtzis, A., Boykin, L.M., Cáceres, C., Cameron, S.L., Chapman, T.A., Chinvinijkul, S., Chomič, A., Meyer, M.D., Drosopoulou, E., Englezou, A., Ekesi, S., Gariou-Papalexiou, A., Geib, S.M., Hailstones, D., Hasanuzzaman, M., Haymer, D., Hee, A.K.W., Hendrichs, J., Jessup, A., Ji, Q., Khamis, F.M., Krosch, M.N., Leblanc, L., Mahmood, K., Malacrida, A.R., Mavragani-Tsipidou, P., Mwatawala, M., Nishida, R., Ono, H., Reyes, J., Rubunoff, D., Sanjose, M., Shelly, T.D., Srikachar, S., Tan, K.H., Thanaphum, S., Haq, I., Vijaysegaran, S., Wee, S.L., Clarke, A.R. 2015a. Synonymization of key pest species within the Bactrocera dorsalis species complex (Diptera: Tephritidae): taxonomic changes based on a review of 20 years of integrative morphological, molecular, cytogenetic, behavioural and chemoecological data. Syst. Entomol. 40(2): 456-471.

Schutze, M. K., Jessup, A., Ul-Haq, I., Vreysen, M. J. B., Wornoayporn, V., Vera, M. T., and Clarke, A. R. 2013. Mating compatibility among four pest members of the Bactrocera dorsalis fruit fly species complex (Diptera: Tephritidae). J. Econ. Entomol. 106(2): $695-707$.

Schutze, M.K., Krosch, M.N., Armstrong, K.F, Chapmanl, T.A., Englezou, A., Chomič, A., Cameron, S.L., Hailstones, D., and Clarke, A.R. 2012. Population structure of Bactrocera dorsalis s.s., B. papayae and B. philippinenses (Diptera: Tephritidae) in southeast Asia: evidence for a single species hypothesis using mitochondrial DNA and wing-shape data. BMC Evol. Biol. 12: 130.

Schutze, M.K., Mahmood, K., Pavasovic, A., Newman, J., Clarke, A.R., Krosch, M.N., and Cameron, S.L. 2015b. One and the same: integrative taxonomic evidence that the African Invasive Fruit Fly Bactrocera invadens (Diptera: Tephritidae), is the same species as the Oriental Fruit Fly Bactrocera dorsalis. Syst. Entomol. 40(2): 472-486.

Sumrandee, C., Milne, J. R., and Baimai, V. 2011. Ovipositor morphology and host relations 
of the Bactrocera tau complex (Diptera: Tephritidae) in Thailand. SJST. 33(3): 247.

Tamura, K., Stecher, G., Peterson, D., Filipski, A., and Kumar, S. 2013. MEGA6: Molecular Evolutionary Genetics Analysis version 6.0. Mol. Biol. Evol. 30: 2725-2729.

Thanaphum, S., and Thaenkham, U. 2003. Relationships of forms within the Bactrocera tau (Walker) (Diptera: Tephritidae) taxon based on heat shock protein 70 cognate sequences. Ann. Entomol. Soc. Am. 96(1): 44-53.

Thompson, J. D., Gibson, T. J., Plewniak, F., Jeanmougin, F., and Higgins, D. G. (1997) The ClustalX windows interface: Flexible strategies for multiple sequence alignment aided by quality analysis tools. Nucleic Acids Res. 24: 4876 - 4882.

Uchôa, M.A. (2012) Fruit flies (Diptera: Tephritoidea): Biology, host plants, natural enemies, and the implications to their natural control. In Integrated Pest Management and Pest Control - Current and Future Tactics. Edited by M. L. Larramendy and S. Soloneski. InTech Publisher, Rijeka, Croatia, pp. $271-300$.

Van Houdt, J.K.J., Breman, F.C., Virgilio, M., and De Meyer, M. 2010. Recovering full DNA barcodes from natural history collections of Tephritid fruitflies (Tephritidae, Diptera) using mini barcodes. Mol. Ecol. Resour. 10(3): 459-465.

Virgilio, M., Backeljau, T., Nevado, B., and Meyer, M.D. 2010. Comparative performances of DNA barcoding across insect orders. BMC Bioinformatics, 11: 206.

White, I.M., and Elson-Harris, M.M. 1992. Fruit Flies of Economic Significance: Their Identification and Bionomics. CAB International, Wallingford.

Zacharopoulou, A., Augustinos, A.A., Sayed, W.A., Robinson, A.S., and Franz, G. 2011. Mitotic and polytene chromosomes analysis of the oriental fruit fly, Bactrocera dorsalis (Hendel) (Diptera: Tephritidae). Genetica, 139(1): 79-90. 
Table 1. Details of specimen collection sites of fruit flies in this study.

\begin{tabular}{|c|c|c|c|c|}
\hline Location & Code & Geographic region & Latitude / Longitude & Elevation (m) \\
\hline Fang, Chaing Mai Province & CMI & North & $18^{\circ} 32^{\prime} 36^{\prime \prime} \mathrm{N} / 98^{\circ} 31^{\prime} 03^{\prime \prime} \mathrm{E}$ & 1330 \\
\hline Mueang Chaing Rai, Chiang Rai Province & CRI1 & North & $19^{\circ} 51^{\prime} 17^{\prime \prime} \mathrm{N} / 99^{\circ} 53^{\prime} 21^{\prime \prime} \mathrm{E}$ & 122 \\
\hline Mae Chan, Chiang Rai Province & CRI2 & North & $20^{\circ} 11^{\prime} 28^{\prime \prime} \mathrm{N} / 99^{\circ} 56^{\prime} 47^{\prime \prime} \mathrm{E}$ & 409 \\
\hline Mueang Lampang, Lampang Province & LPG1 & North & $18^{\circ} 17^{\prime} 01^{\prime \prime} \mathrm{N} / 99^{\circ} 30^{\prime} 09^{\prime \prime} \mathrm{E}$ & 229 \\
\hline Mae Mo, Lampang Province & LPG2 & North & $18^{\circ} 24^{\prime} 29^{\prime \prime} \mathrm{N} / 99^{\circ} 51^{\prime} 25^{\prime \prime} \mathrm{E}$ & 598 \\
\hline Wang Nuea, Lampang Province & LPG3 & North & $19^{\circ} 04^{\prime} 11^{\prime \prime} \mathrm{N} / 99^{\circ} 43^{\prime} 45^{\prime \prime} \mathrm{E}$ & 607 \\
\hline Mae La Noi, Mae Hong Son Province & MSN1 & North & $18^{\circ} 22^{\prime} 39^{\prime \prime} \mathrm{N} / 97^{\circ} 56^{\prime} 30^{\prime \prime} \mathrm{E}$ & 315 \\
\hline Pai, Mae Hong Son Province & MSN2 & North & $19^{\circ} 26^{\prime} 45 \mathrm{~N} / 98^{\circ} 19^{\prime} 09^{\prime \prime} \mathrm{E}$ & 1430 \\
\hline Mueang Phayao, Phayao Province & PYO & North & $19^{\circ} 13^{\prime} 03 \mathrm{~N} / 99^{\circ} 44^{\prime} 16^{\prime \prime} \mathrm{E}$ & 572 \\
\hline Long, Phrae Province & PRE & North & $18^{\circ} 00^{\prime} 53 \mathrm{~N} / 99^{\circ} 42^{\prime} 55^{\prime \prime} \mathrm{E}$ & 156 \\
\hline Kaset Sombun, Chaiyaphum Province & CPM & Northeast & $16^{\circ} 22^{\prime} 45^{\prime \prime} \mathrm{N} / 101^{\circ} 58^{\prime} 22^{\prime \prime} \mathrm{E}$ & 226 \\
\hline Mueang Khon Kaen, Khon Kaen Province & $\mathrm{KKN}$ & Northeast & $16^{\circ} 32^{\prime} 41^{\prime \prime} \mathrm{N} / 102^{\circ} 50^{\prime} 37^{\prime \prime} \mathrm{E}$ & 173 \\
\hline Na Haeo, Loei Province & LEI & Northeast & $17^{\circ} 21^{\prime} 17^{\prime \prime} \mathrm{N} / 101^{\circ} 03^{\prime} 42^{\prime \prime} \mathrm{E}$ & 794 \\
\hline Mueng Maha Sarakham, Maha Sarakham Province & MKM1 & Northeast & $16^{\circ} 08^{\prime} 13 \mathrm{~N} / 103^{\circ} 18^{\prime} 33^{\prime \prime} \mathrm{E}$ & 159 \\
\hline Kantharawichai, Maha Sarakham Province & MKM2 & Northeast & $16^{\circ} 15^{\prime} 17 \mathrm{~N} / 103^{\circ} 13^{\prime} 50^{\prime \prime} \mathrm{E}$ & 150 \\
\hline Nong Sung Mukdahan, Mukdahan Province & $\mathrm{MDH}$ & Northeast & $16^{\circ} 27^{\prime} 38 \mathrm{~N} / 104^{\circ} 26^{\prime} 26^{\prime \prime} \mathrm{E}$ & 204 \\
\hline Mueang Nong Khai, Nong Khai Province & NKI1 & Northeast & $17^{\circ} 48^{\prime} 59 \mathrm{~N} / 102^{\circ} 42^{\prime} 58^{\prime \prime} \mathrm{E}$ & 181 \\
\hline Si Chiang Mai, Nong Khai Province & NKI2 & Northeast & $17^{\circ} 56^{\prime} 28 \mathrm{~N} / 102^{\circ} 35^{\prime} 43^{\prime \prime} \mathrm{E}$ & 252 \\
\hline
\end{tabular}




\begin{tabular}{|c|c|c|c|c|}
\hline Location & Code & Geographic region & Latitude / Longitude & Elevation (m) \\
\hline Nong Phok, Roi-Et Province & RET & Northeast & $16^{\circ} 18^{\prime} 35 \mathrm{~N} / 104^{\circ} 12^{\prime} 11^{\prime \prime} \mathrm{E}$ & 179 \\
\hline Prang Ku, Si Sa Ket Province & SSK & Northeast & $14^{\circ} 49^{\prime} 43 \mathrm{~N} / 104^{\circ} 03^{\prime} 32^{\prime \prime} \mathrm{E}$ & 136 \\
\hline $\begin{array}{l}\text { Mueang Ubon Ratchathani, } \\
\text { Ubon Ratchathani Province }\end{array}$ & UBN & Northeast & $15^{\circ} 13^{\prime} 44 \mathrm{~N} / 104^{\circ} 51^{\prime} 15^{\prime \prime} \mathrm{E}$ & 121 \\
\hline Mueang Chanthaburi, Chanthaburi Province & CTI1 & East & $12^{\circ} 36^{\prime} 25^{\prime \prime} \mathrm{N} / 102^{\circ} 04^{\prime} 49^{\prime \prime} \mathrm{E}$ & 10 \\
\hline Laem Sing, Chanthaburi Province & CTI2 & East & $12^{\circ} 28^{\prime} 26^{\prime \prime} \mathrm{N} / 102^{\circ} 05^{\prime} 32^{\prime \prime} \mathrm{E}$ & 11 \\
\hline $\begin{array}{l}\text { Mueang Kamphaeng Phet, } \\
\text { Kamphaeng Phet Province }\end{array}$ & KPT & Central & $16^{\circ} 26^{\prime} 04^{\prime \prime} \mathrm{N} / 99^{\circ} 22^{\prime} 06^{\prime \prime} \mathrm{E}$ & 98 \\
\hline Mueang Nakhon Pathom, Nakhon Pathom Province & NPT & Central & $13^{\circ} 50^{\prime} 32 \mathrm{~N} / 100^{\circ} 01^{\prime} 24^{\prime \prime} \mathrm{E}$ & 10 \\
\hline
\end{tabular}


Table 2. Fruit fly species and host plants collected in this study.

\begin{tabular}{|c|c|c|c|c|c|}
\hline \multirow[t]{2}{*}{ Fruit fly species } & \multicolumn{2}{|l|}{ Host plants } & \multirow[t]{2}{*}{ Source } & \multirow{2}{*}{$\begin{array}{l}\text { Number } \\
\text { of fruit } \\
\text { flies }\end{array}$} & \multirow{2}{*}{$\begin{array}{l}\text { Sampling } \\
\text { Location }^{b}\end{array}$} \\
\hline & Family & Species & & & \\
\hline B. (Bactrocera) carambolae & Myrtaceae & Psidium guajava $\mathrm{L}$. & Fruit orchards & 1 & CRI1 \\
\hline Drew \& Hancock & & $\begin{array}{l}\text { Syzygium samarangense (Blume) Merr \& } \\
\text { L.M. Perry }\end{array}$ & Fruit orchards & 4 & $\mathrm{MDH}$ \\
\hline \multirow{12}{*}{$\begin{array}{l}\text { B. (Bactrocera) correcta } \\
\text { (Bezzi) }\end{array}$} & Anacardiaceae & Mangifera indica $\mathrm{L}$. & Fruit orchards & 1 & RET \\
\hline & Anacardiaceae & Mangifera indica $\mathrm{L}$. & Fruit orchards & $13^{\mathrm{a}}$ & \\
\hline & Annonaceae & Artabotrys siamensis Mig. & Fruit orchards & $1^{\mathrm{a}}$ & \\
\hline & Cucurbitaceae & Coccinia grandis (L.) Voigt & Fruit orchards & $1^{\mathrm{a}}$ & \\
\hline & Irvingiaceae & Irvingia malayana Oliv. ex A.W. Benn. & Wild fruits & $2^{\mathrm{a}}$ & \\
\hline & Malpighiaceae & Malpighia glabra L. & Fruit orchards & $13^{\mathrm{a}}$ & \\
\hline & Myrtaceae & $\begin{array}{l}\text { Syzygium samarangense (Blume) Merr \& } \\
\text { L.M. Perry }\end{array}$ & Fruit orchards & $61^{\mathrm{a}}$ & \\
\hline & & Psidium guajava $\mathrm{L}$. & Fruit orchards & $50^{\mathrm{a}}$ & \\
\hline & Oxalidaceae & Averrhoa carambola L. & Fruit orchards & $7^{\mathrm{a}}$ & \\
\hline & Solanaceae & Solanum melongena $\mathrm{L}$. & Fruit orchards & $8^{\mathrm{a}}$ & \\
\hline & Tiliaceae & Muntingia calabura $\mathrm{L}$. & Fruit orchards & $1^{\mathrm{a}}$ & \\
\hline & Verbenaceae & Ziziphus mauritiana Lam. & Fruit orchards & $14^{\mathrm{a}}$ & \\
\hline B. (Zeugodacus) cucurbitae & Cucurbitaceae & Coccinia grandis (L.) Voigt & Wild fruits & 7 & $\mathrm{CMI}, \mathrm{KPT}$ \\
\hline \multirow{3}{*}{ (Coquillett) } & & Cucurbita moschata Duchesne & Fruit orchards & 2 & MKM2 \\
\hline & & Luffa cylindrica (L.) M. Roem. & Fruit orchards & 1 & PYO, PRE \\
\hline & & Gymnopetatum integrifolium (Roxb.) Kurz & Fruit orchards & 4 & SSK \\
\hline $\begin{array}{l}\text { B. (Hemigymnodacus) diversa } \\
\text { (Coquillett) }\end{array}$ & Cucurbitaceae & Cucurbita moschata Duchesne & Fruit orchards & 1 & NKI2 \\
\hline \multirow{4}{*}{$\begin{array}{l}\text { B. (Bactrocera) dorsalis } \\
\text { (Hendel) }\end{array}$} & Anacardiaceae & Mangifera indica $\mathrm{L}$. & Fruit orchards & 1 & CPM, CTI1 \\
\hline & Annonaceae & Annona squamosa L. & Fruit orchards & 3 & MKM1 \\
\hline & Myrtaceae & Psidium guajava $\mathrm{L}$. & Fruit orchards & 4 & MKM2 \\
\hline & & $\begin{array}{l}\text { Syzygium samarangense (Blume) Merr \& } \\
\text { L.M. Perry }\end{array}$ & Fruit orchards & 12 & NPT, NKI1 \\
\hline
\end{tabular}




\begin{tabular}{|c|c|c|c|c|c|}
\hline \multirow[t]{3}{*}{ Fruit fly species } & \multicolumn{2}{|l|}{ Host plants } & \multirow[t]{2}{*}{ Source } & \multirow{2}{*}{$\begin{array}{l}\text { Number } \\
\text { of fruit } \\
\text { flies }\end{array}$} & \multirow{2}{*}{$\begin{array}{l}\text { Sampling } \\
\text { Location }^{b}\end{array}$} \\
\hline & Family & Species & & & \\
\hline & Verbenaceae & Ziziphus mauritiana Lam. & Fruit orchards & 1 & SSK, UBN \\
\hline \multirow{7}{*}{$\begin{array}{l}\text { B. (Bactrocera) invadens } \\
\text { Drew, Tsuruta \& White } \\
(=B .(\text { Bactrocera }) \text { dorsalis } \\
\text { (Hendel) })\end{array}$} & Anacardiaceae & Mangifera indica $\mathrm{L}$. & Fruit orchards & 1 & KKN, SSK \\
\hline & Annonaceae & Annona squamosa $\mathrm{L}$. & Fruit orchards & 1 & MKM1 \\
\hline & Myrtaceae & Psidium guajava $\mathrm{L}$. & Fruit orchards & 2 & MKM2 \\
\hline & & $\begin{array}{l}\text { Syzygium samarangense (Blume) Merr \& } \\
\text { L.M. Perry }\end{array}$ & Fruit orchards & 1 & \\
\hline & Oxalidaceae & Averrhoa carambola $\mathrm{L}$. & Fruit orchards & 1 & \\
\hline & Sapindaceae & Dimocarpus longan Lour. & Fruit orchards & 1 & \\
\hline & Verbenaceae & Ziziphus mauritiana Lam. & Fruit orchards & 1 & \\
\hline \multirow{4}{*}{$\begin{array}{l}\text { B. (Bactrocera) papayae } \\
\text { Drew \& Hancock } \\
(=B .(\text { Bactrocera }) \text { dorsalis } \\
\text { (Hendel }))\end{array}$} & Anacardiaceae & Mangifera indica $\mathrm{L}$. & Fruit orchards & 4 & CPM, \\
\hline & Ebenaceae & Diospyros decandra Lour. & Fruit orchards & 1 & MKM2 \\
\hline & Myrtaceae & $\begin{array}{l}\text { Syzygium samarangense (Blume) Merr \& } \\
\text { L.M. Perry }\end{array}$ & Fruit orchards & 1 & SSK \\
\hline & Oxalidaceae & Averrhoa carambola $\mathrm{L}$. & Fruit orchards & 2 & \\
\hline \multirow{4}{*}{$\begin{array}{l}\text { B. (Bactrocera }) \text { philippinensis } \\
\text { Drew \& Hancock } \\
(=\text { B. (Bactrocera) dorsalis } \\
\text { (Hendel) })\end{array}$} & Annonaceae & Annona squamosal L. & Fruit orchards & 2 & MKM2 \\
\hline & Irvingiaceae & Irvingia malayana Oliv. ex A.W. Benn. & Fruit orchards & 1 & NKI1 \\
\hline & Myrtaceae & Psidium guajava $\mathrm{L}$. & Fruit orchards & 1 & SSK \\
\hline & & $\begin{array}{l}\text { Syzygium samarangense (Blume) Merr \& } \\
\text { L.M. Perry }\end{array}$ & Fruit orchards & 1 & \\
\hline \multirow{7}{*}{$\begin{array}{l}\text { B. (Bactrocera) latifrons } \\
\text { (Hendel) }\end{array}$} & Solanaceae & Capsicum frutescens $\mathrm{L}$. & Fruit orchards & 1 & CTI2, CRI1 \\
\hline & & Solanum melongena $\mathrm{L}$. & Fruit orchards & 3 & LPG1, RET \\
\hline & & Lycopersicon esculentum Mill. & Fruit orchards & 1 & \\
\hline & & Capsicum frutescens $\mathrm{L}$. & Fruit orchards & $55^{\mathrm{a}}$ & \\
\hline & & Solanum melongena $\mathrm{L}$. & Fruit orchards & $7^{\mathrm{a}}$ & \\
\hline & & Solanum torvum $\mathrm{Sw}$. & Fruit orchards & $14^{\mathrm{a}}$ & \\
\hline & & Solanum trilobatum L. & Fruit orchards & $21^{\mathrm{a}}$ & \\
\hline $\begin{array}{l}\text { B. (Zeugodacus) scutellaris } \\
\text { (Bezzi) }\end{array}$ & Cucurbitaceae & Cucurbita moschata Duchesne & Wild fruits & 4 & MSN2 \\
\hline B. (Zeugodacus) tau (Walker) & Cucurbitaceae & Coccinia grandis (L.) Voigt & Wild fruits & 3 & CPM, CRI2 \\
\hline
\end{tabular}




\begin{tabular}{|c|c|c|c|c|c|}
\hline \multirow[t]{2}{*}{ Fruit fly species } & \multicolumn{2}{|l|}{ Host plants } & \multirow[t]{2}{*}{ Source } & \multirow{2}{*}{$\begin{array}{l}\text { Number } \\
\text { of fruit } \\
\text { flies }\end{array}$} & \multirow{2}{*}{$\begin{array}{l}\text { Sampling } \\
\text { Location }^{b}\end{array}$} \\
\hline & Family & Species & & & \\
\hline & & Momordica cochinchinensis (Lour.) & Fruit orchards & 5 & LPG2, LEI \\
\hline & & Gymnopetalum integrifolium (Roxb.) Kurz & Wild fruits & 16 & PYO \\
\hline $\begin{array}{l}\text { B. (Bactrocera) thailandica } \\
\text { Drew \& Hancock }\end{array}$ & Myrtaceae & Psidium guajava $\mathrm{L}$. & Fruit orchards & 9 & CMI \\
\hline $\begin{array}{l}\text { B. (Bactrocera) tuberculata } \\
\text { (Bezzi) }\end{array}$ & Barringtoniaceae & Careya sphaerica Roxb. & Wild fruits & 7 & MKM1 \\
\hline $\begin{array}{l}\text { B. (Gymnodacus) symplocos } \\
\text { Drew \& Romig }\end{array}$ & Anacardiaceae & Spondias pinnata (L.f.) Kurz & Wild fruits & 7 & LPG3 \\
\hline Bactrocera sp. 1 & Cucurbitaceae & Coccinia grandis (L.) Voigt & Wild fruits & 4 & MSN1 \\
\hline Total & & ( & & 391 & \\
\hline
\end{tabular}

${ }^{a}$ Sequences obtained from GenBank. ${ }^{b}$ Details of the locations are given in Table 1. 
Table 3. Intraspecific Kimura 2-parameter (K2P) genetic divergence and distance to nearest neighbor of 17 fruit fly species based on mitochondrial cytochrome c oxidase I sequences.

\begin{tabular}{|c|c|c|c|c|c|c|}
\hline \multirow{3}{*}{ Species } & \multicolumn{4}{|c|}{ Number of COI sequences } & \multirow{3}{*}{$\begin{array}{l}\text { Percent } \\
\text { intraspecific } \\
\text { genetic divergence } \\
\text { (mean) }\end{array}$} & \multirow{3}{*}{$\begin{array}{l}\text { Percent pairwise } \\
\text { K2P distance to the } \\
\text { closest species } \\
\text { (mean) }\end{array}$} \\
\hline & \multirow[b]{2}{*}{ This study } & \multicolumn{2}{|c|}{ GenBank } & \multirow[b]{2}{*}{$\begin{array}{l}\text { Total } \\
\text { (number of } \\
\text { haplotypes) }\end{array}$} & & \\
\hline & & Thailand & $\begin{array}{l}\text { Other } \\
\text { countries }\end{array}$ & & & \\
\hline B. (Zeugodacus) caudata & - & 3 & - & $3(2)$ & $0.15-0.61(0.40)$ & $7.14-7.79(7.32)$ \\
\hline B. (Bactrocera) correcta & 1 & 185 & 24 & $210(99)$ & $0-3.80(1.23)$ & $6.69-10.00(7.72)$ \\
\hline B. (Zeugodacus) cucurbitae & 14 & - & 119 & $133(23)$ & $0-4.43(0.17)$ & $0.88-5.88(5.06)$ \\
\hline B. (Hemigymnodacus) diversa & 1 & - & 10 & $11(9)$ & $0-1.70(0.86)$ & $7.14-7.79(7.32)$ \\
\hline B. (Zeugodacus) isolata & - & 2 & - & $2(1)$ & 0 & $12.17-12.83(12.56)$ \\
\hline B. (Bactrocera) latifrons & 5 & 97 & 33 & $135(47)$ & $0-1.70(0.30)$ & $11.21-13.92(11.95)$ \\
\hline B. (Zeugodacus) rubella & - & 7 & - & $7(3)$ & $0-1.33(0.38)$ & $11.00-13.33(11.75)$ \\
\hline B. (Zeugodacus) scutellaris & 4 & - & 18 & $22(16)$ & $0-1.10(0.15)$ & $11.00-13.33(11.75)$ \\
\hline B. (Zeugodacus) tau & 24 & - & 79 & $103(51)$ & $0-1.10(0.32)$ & $0.88-5.88(5.06)$ \\
\hline B. (Bactrocera) tuberculata & 7 & - & 5 & $12(7)$ & $0-5.60(2.77)$ & $5.90-10.59(7.65)$ \\
\hline B. (Bactrocera) umbrosa & - & 10 & - & $10(2)$ & $0-0.30(0.09)$ & $10.71-11.60(11.06)$ \\
\hline B. (Bactrocera) zonata & - & 3 & - & $3(2)$ & $0-0.61(0.41)$ & $6.69-10.00(7.72)$ \\
\hline B. (Gymnodacus) symplocos & 7 & - & - & $7(6)$ & $0-1.40(0.65)$ & $10.71-11.60(11.06)$ \\
\hline Bactrocera sp. 1 & 4 & - & - & $4(3)$ & $0-2.80(1.40)$ & $12.91-15.88(14.19)$ \\
\hline B. (Bactrocera) carambolae & 5 & - & 82 & $87(40)$ & $0-3.70(0.61)$ & $0-9.80(1.35)$ \\
\hline B. (Bactrocera) dorsalis & 21 & 7 & 199 & $227(115)$ & $0-10.47(0.93)$ & $0-9.80(1.35)$ \\
\hline B. (Bactrocera) thailandica & 9 & - & 13 & $22(4)$ & $0-0.80(0.14)$ & $1.83-9.14(2.87)$ \\
\hline Total & 123 & 314 & 709 & $1146(461)$ & $0-10.47(0.64)$ & $0-15.88(8.10)$ \\
\hline
\end{tabular}


Table 4. DNA barcode statistics for 17 fruit fly species based on best match and best-close match methods in TaxonDNA (Meier et al. 2006).

\begin{tabular}{lll}
\hline & Best match & Best close match \\
\hline Correct identification (n) & $96.50 \%$ (1 106 sequences) & $96.42 \%$ (1 105 sequences) \\
Misidentification (n) & $0.61 \%$ (7 sequences) & $0.52 \%$ (6 sequences) \\
Ambiguous identification (n) & $2.87 \%$ (33 sequences) & $2.87 \%$ (33 sequences) \\
Sequences without any match closer than threshold value & 0 & $0.17 \%(2$ sequences $)$ \\
\hline Threshold $^{a}$ & - & $2.05 \%$
\end{tabular}

${ }^{a}$ Threshold value is genetic distance at $95 \%$ of all intraspecific genetic distances (Meier et al. 2006). 


\section{Figure legends}

Fig. 1. Collection sites of fruit flies in Thailand. Details of sampling sites are given in Table 1.

Fig. 2. Range of intraspecific Kimura 2-parameter genetic distances and pairwise divergences to the closest species for 17 species of fruit flies of the genus Bactrocera based on the barcode region of the mitochondrial cytochrome c oxidase I sequences.

Fig. 3. Maximum likelihood tree for cytochrome c oxidase I (COI) sequences of 17 species of the fruit fly genus Bactrocera. Members of Bactrocera dorsalis complex were treated as one species. Variability within each morphospecies was collapsed into triangle for visualization. Node support based on likelihood ratio test is shown above or near branch. Scale bar represents 0.04 substitutions per nucleotide position. Numbers in parentheses represent the total number of sequences followed by number of haplotypes of each species. Host plant families of each fruit fly species are shown next to the taxon name, with the number of fruit fly specimens for each plant family shown inside the legend. Asterisks indicate that the host plant family for sequences from GenBank was unknown, and thus, only the numbers of specimens from present study were shown. Question marks indicate that the host plant is unknown.

Fig. 4. Maximum likelihood tree for cytochrome c oxidase I (COI) barcode sequences of 190 unique sequences of members of the Bactrocera dorsalis complex. Node support based on likelihood ratio test is shown above or near branch. Scale bar represents 0.04 substitutions per nucleotide position. Numbers in parentheses represent the number of haplotypes of each species.

Fig. 5. Maximum likelihood tree for cytochrome c oxidase I (COI) barcode sequences of 99 unique sequences of Bactrocera correcta. Node support based on likelihood ratio test is shown above or near branch. Scale bar represents 0.04 substitutions per nucleotide position. 
Host plant families of each haplotype are shown. Question marks indicate that the host plant is unknown. 


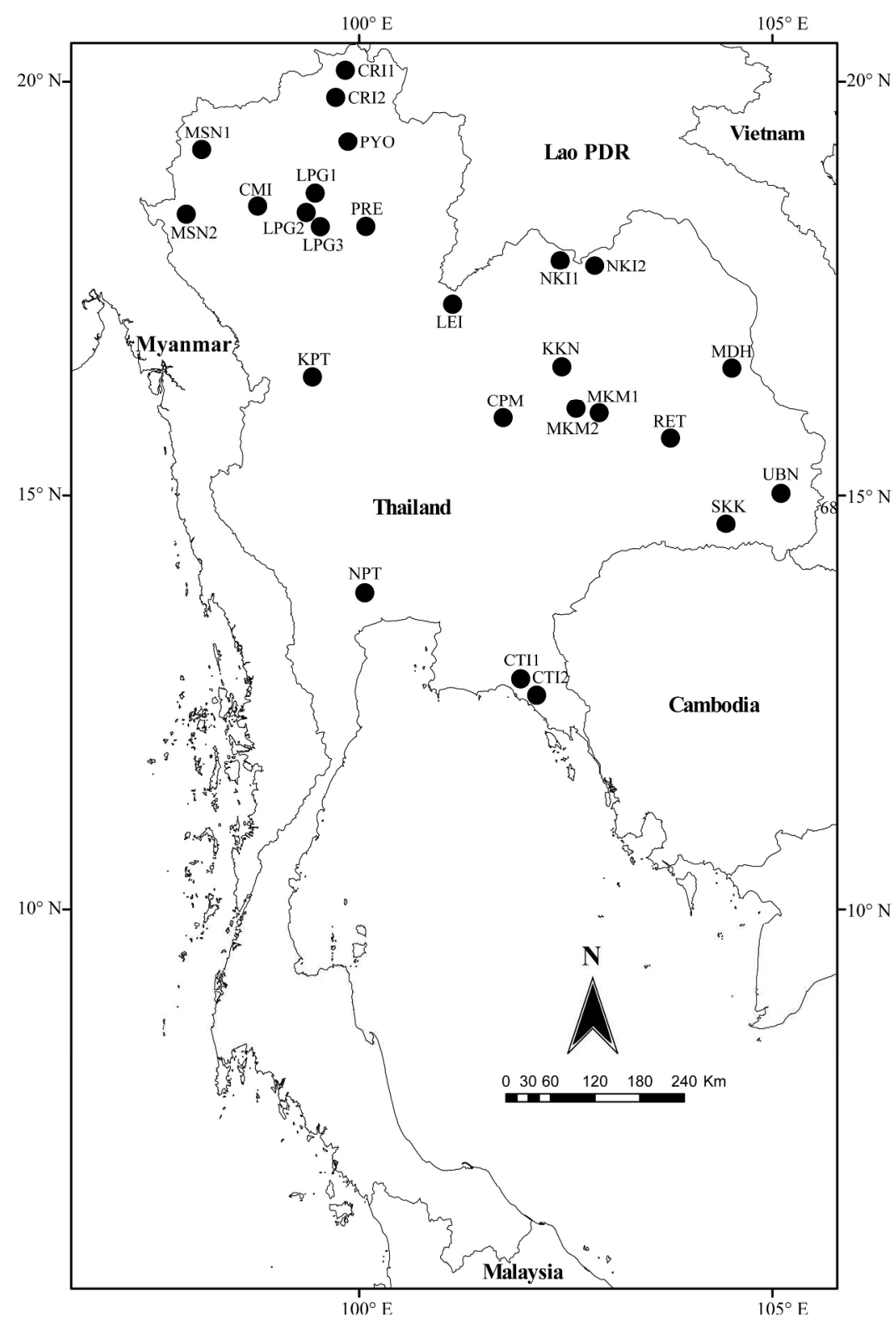

Fig. 1. Collection sites of fruit flies in Thailand. Details of sampling sites are given in Table 1. $\backslash \mathrm{r} \backslash \mathrm{n}$ $205 \times 293 \mathrm{~mm}(300 \times 300$ DPI $)$ 


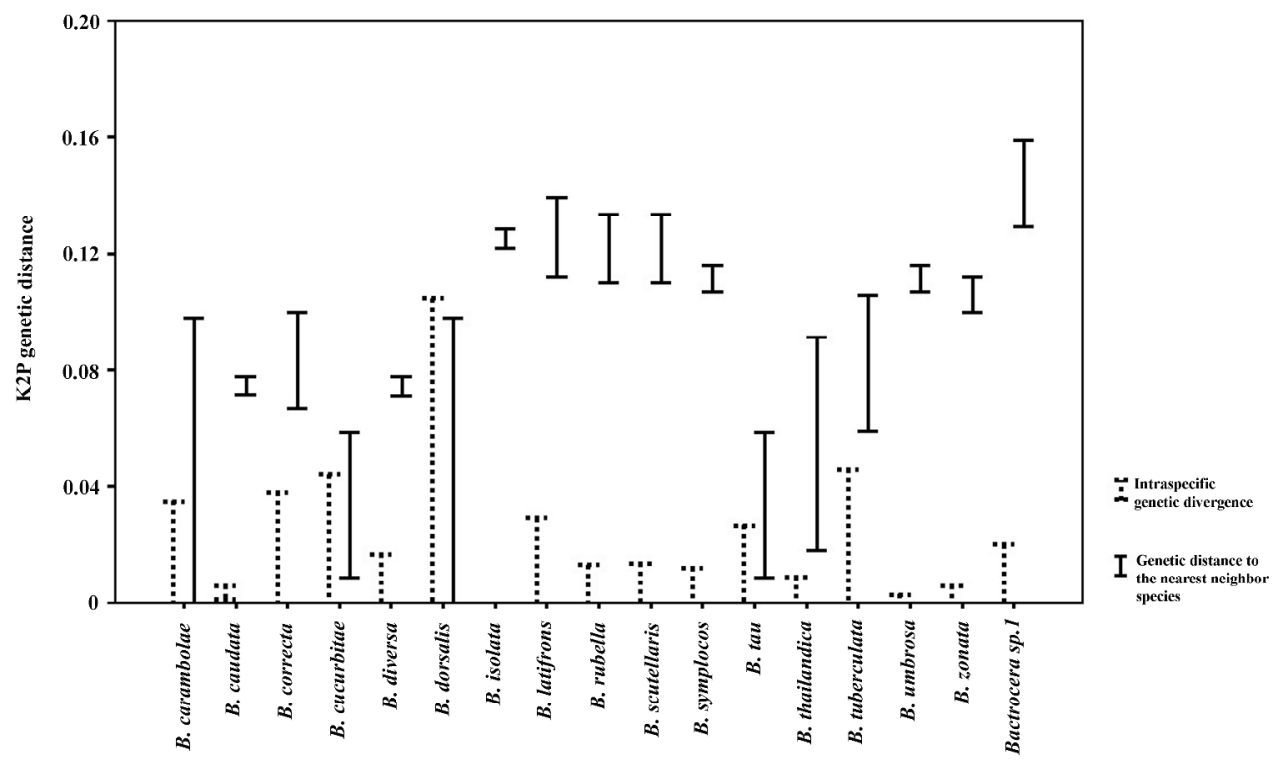

Fig. 2. Range of intraspecific Kimura 2-parameter genetic distances and pairwise divergences to the closest species for 17 species of fruit flies of the genus Bactrocera based on the barcode region of the mitochondrial cytochrome c oxidase I sequences.

$303 \times 197 \mathrm{~mm}(300 \times 300$ DPI) 


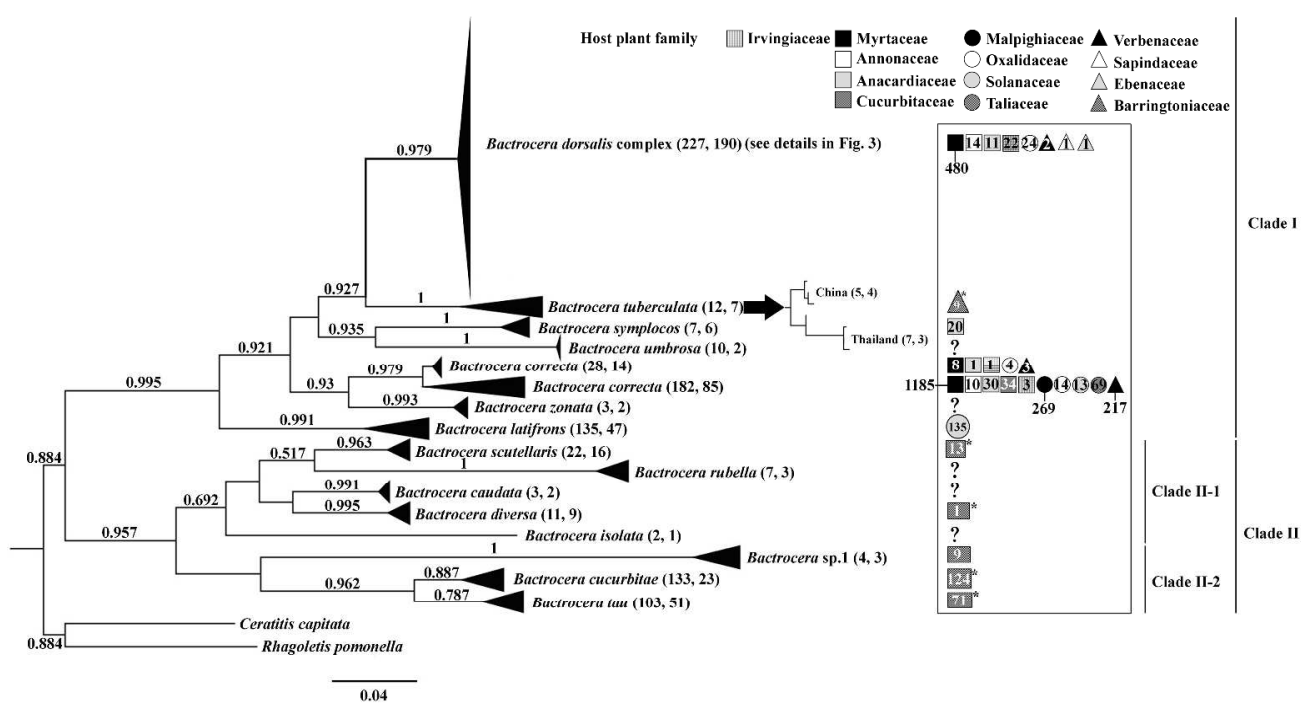

Fig. 3. Maximum likelihood tree for cytochrome c oxidase I (COI) sequences of 17 species of the fruit fly genus Bactrocera. Members of Bactrocera dorsalis complex were treated as one species. Variability within each morphospecies was collapsed into triangle for visualization. Node support based on likelihood ratio test is shown above or near branch. Scale bar represents 0.04 substitutions per nucleotide position. Numbers in parentheses represent the total number of sequences followed by number of haplotypes of each species. Host plant families of each fruit fly species are shown next to the taxon name, with the number of fruit fly specimens for each plant family shown inside the legend. Asterisks indicate that the host plant family for sequences from GenBank was unknown, and thus, only the numbers of specimens from present study were shown. Question marks indicate that the host plant is unknown. $525 \times 284 \mathrm{~mm}(300 \times 300 \mathrm{DPI})$ 

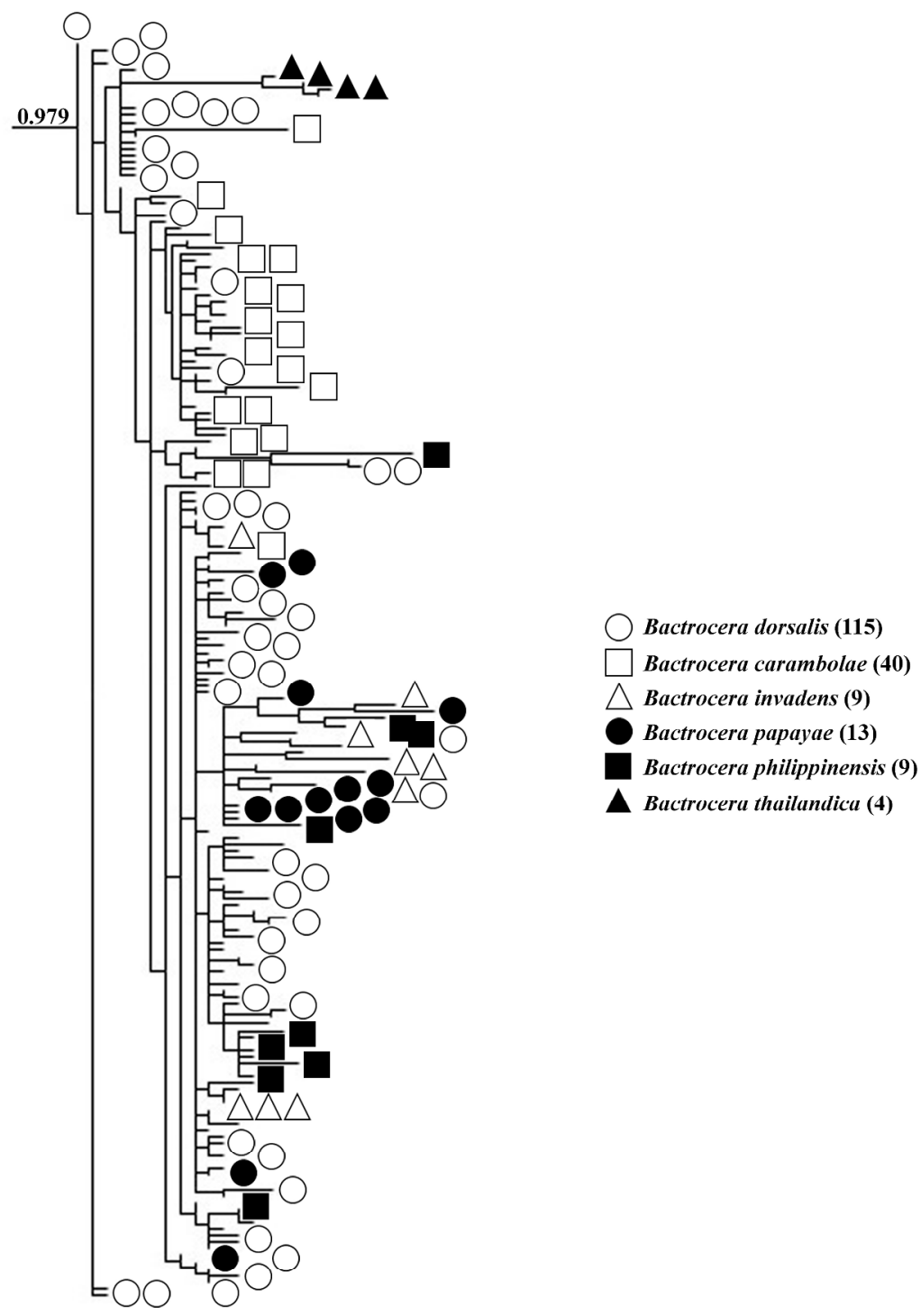

0.04

Fig. 4. Maximum likelihood tree for cytochrome c oxidase I (COI) barcode sequences of 190 unique sequences of members of the Bactrocera dorsalis complex. Node support based on likelihood ratio test is shown above or near branch. Scale bar represents 0.04 substitutions per nucleotide position. Numbers in parentheses represent the number of haplotypes of each species.

$172 \times 207 \mathrm{~mm}(600 \times 600 \mathrm{DPI})$ 


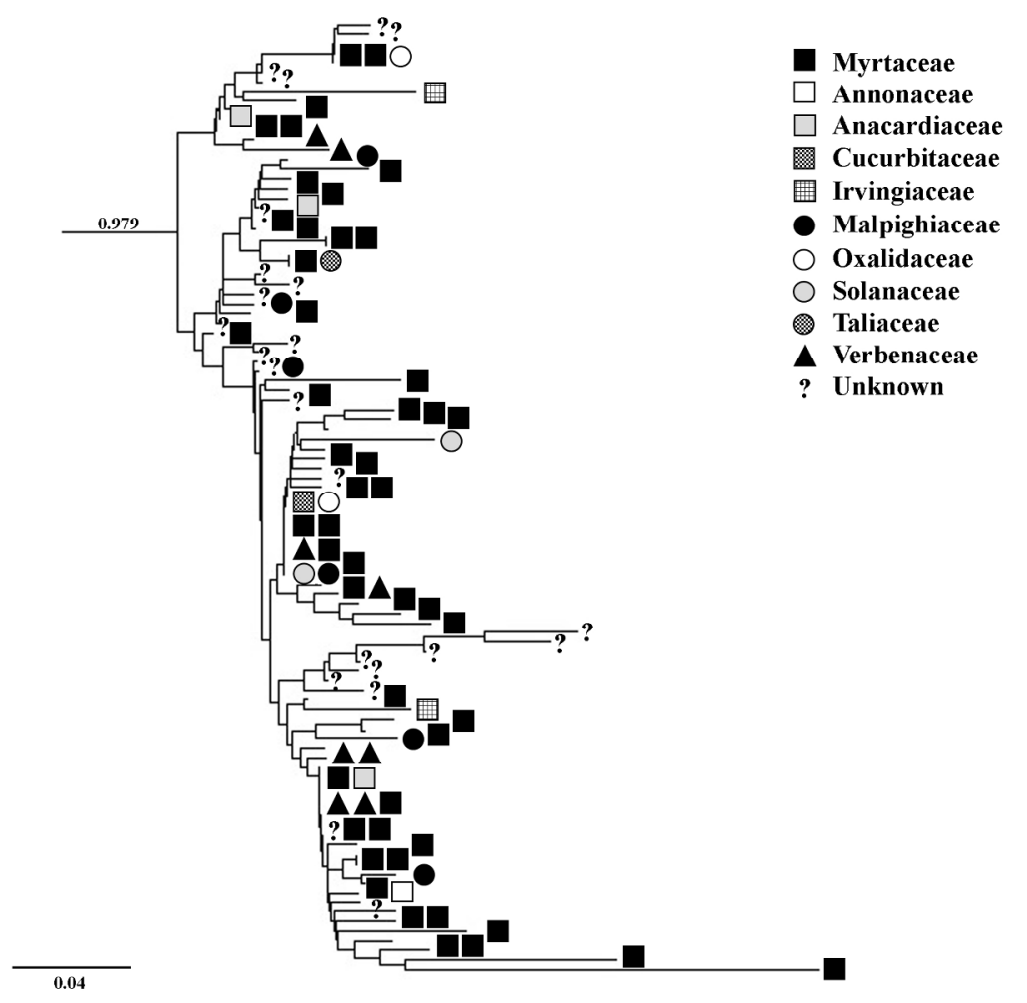

Fig. 5. Maximum likelihood tree for cytochrome c oxidase I (COI) barcode sequences of 99 unique sequences of Bactrocera correcta. Node support based on likelihood ratio test is shown above or near branch. Scale bar represents 0.04 substitutions per nucleotide position. Host plant families of each haplotype are shown. Question marks indicate that the host plant is unknown.

$204 \times 168 \mathrm{~mm}$ (300 x 300 DPI) 